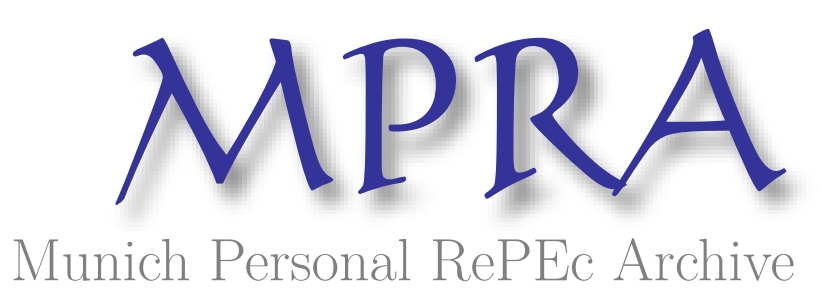

\title{
The Modern Corporation and Private Property - 80 Years Later
}

Nedelchev, Miroslav

June 2012

Online at https://mpra.ub.uni-muenchen.de/64542/

MPRA Paper No. 64542, posted 24 May 2015 05:12 UTC 


\title{
THE MODERN CORPORATION AND PRIVATE PROPERTY - 80 YEARS LATER
}

\author{
Assos. Prof. Miroslav Nedelchev PhD*
}

\begin{abstract}
The events that took place since 2007 raised new challenges to the economy. The traditional approaches to the corporate governance and to the private property are reshaped. The interests of the society and of the national economy win the upper hand against the interests of the company. The participants and the instruments of the corporate governance are surrounded by a new reality.
\end{abstract}

KEYWORDS: corporate governance, SMART

\begin{abstract}
„The rise of the modern corporation led to a concentration of economic power that is comparable with the power of the modern state. "

A. Berle and G. Means, „The modern corporation and private property" (1932)
\end{abstract}

\section{Introduction}

The events of 2007 posed new challenges to the global economy. Proven models and management practices have been criticized. Existing concepts and theories about the role of the market and the state are subject to revision. Private-law relations „shareholder-manager“ reviewed as the model ,principal-agent" placed in the new institutional framework defined by international organizations. The interests of society take precedence over corporate interests.

In this situation, practice turning to theory. The importance of economic development for society addressing development of a model to meet the expectations of economic agents and stakeholders. In a similar situation in the 1930s, the theory offers a model based on research by A. Berle and G. Means [Berle, A., G. Means. 1932].

In the economic history the mankind succeeds to overcome a series of shocks, the most significant of which is the Great Depression. Regardless of the time lag between the depression of the 1930s and the recession of the early twenty-first century, there are some similarities. In both turning point, deregulation leads to dominance of corporate interests over the public, followed by government intervention in the private-law relationship between shareholders and managers.

The monumental work by A. Berle and G. Means „Modern Corporation and Private Property" is often cited and little rereads [Weidenbaum, M., M. Jensen. 2009: viii]. As an object of study, they analyzed the effectiveness of using the state subsidies granted by the US government to deal with the effects of the economic depression. After summarizing the data of 200 leading US public companies from the real sector, was established the managers use funds for projects which are not in the interest of shareholders. In conclusion, the authors defined that the reason for the inefficient management the fact that the possibility of a decision making is passed by the shareholders to managers. As a consequence, the control over the company separated from ownership. In the spirit of Keynesianism, A. Berle and G. Means introduce requirements for state control over the actions of managers.

\footnotetext{
*Academic Conference „Challenges in contemporary economy“, International Business School, Sofia, 2012, pp. 845-853. ISBN 978-954-9432-57-2 (CD).
} 
Eighty years after the work of A. Berle and G. Means can be noted some similarities in economic development. The world economy is in recession, caused by practices in corporate governance, lack of effective control over the actions of managers and passive participation by shareholders [Organisation for Economic Co-operation and Development. 2009: 13]. Risk appetite has led to excess profits and the need for state intervention to protect the interests of society. State aid to tackle the crisis provided to the private sector in the form of temporarily acquired shares are used inefficiently by the managers of companies.

In the era of A. Berle and G. Means participants in corporate governance are limited to two: shareholders and managers. Shareholders in their capacity as owners of the company delegated management of managers.

Shareholders, in the words of A. Berle and G. Means, are characterized by ,rational apathy" due to dispersion of ownership. Before the Great Depression, in the United States were adopted legislative initiatives aimed at a wider diffusion of ownership. Antitrust laws preclude the formation of cross-ownership between companies. With the introduction of a prohibition commercial banks to hold shares in companies and imposing of financial sanctions on mutual funds that invest more than $5 \%$ of their portfolio in one company, created an environment to increase the number of minority shareholders. Ownership in industries passed into public companies and the management of directors - to professional managers. Government policy on deregulation led to separation of ownership from control in addition to the existing separation of management from ownership. Resulted „,corporate revolution“ due to the dispersion of shareholders property is compared by A. Berle and G. Means with the change of land ownership after the French Revolution.

With the acquisition of a share of a public company the shareholder retained ownership of the stock and conceded the management to managers. While shareholder has statutory restriction to change managers and gradually become passive investor. The participation of shareholders narrowed to trading of their legal status for private property with the role of recipient of return [Weidenbaum, M., M. Jensen. 2009: viii]. Shareholders were similar with renters - anonymous participants with a small share in the capital [Bratton, W. 2001: 737]. The benefit for shareholders by purchasing shares was reduced to receiving „salary in the capital".

Along with the effective separation between management and ownership is increased as the size of the company and the concentration in the economy. Shareholders retained a degree of control by their right to authorize to vote and the right to veto in case of acquisition. On the economic scene comes a new factor on corporate governance - the market for corporate control.

Managers, according A. Berle and G. Means, took control over the company due to the dispersion of ownership. To the traditional activity for management is added new one - setting of the company policy. In this situation, called „managerism“, the right of shareholders for control is transformed by the power of managers to select projects for the development of the company. The economic power is concentrated in a new class of professional managers [Mizruchi, M. 2004: 579]. The behavior of managers do not affects by the view of shareholders, public expectations and the requirements of the state.

At the beginning of the Great Depression, the leading 200 companies controlled 49.2 percent of corporate wealth [Davis, G. 2011: 1207]. A. Berle and G. Means indicated that if the trend be maintained, these companies will become ,the dominant institutions of the modern world“. The private ownership of shareholders became „economic empires“ that are „,in the hands of a new form of absolutism on ownership“. Companies already looked like a classic entrepreneur in the face of the managers who ran against salary. 
The separation of ownership from control removes the instruments of shareholders to monitor the actions of managers. With the new power the managers expected pursue their goals using capital of shareholders. Managers' interests began to diverge with those of shareholders. The separation of ownership from control created ,quasi-public companies“.

Writing „Modern Corporation and Private Property“ reflects three trends in economic development: increasing of concentration; increase the dispersion of share ownership; separation of control from ownership [Means, G. 2009: xlix]. The modern corporation from 1930s is a dominant factor in the national economy and private property - dispersed.

The modern corporation since the beginning of the XXI century is dominant in the global economy, over which national governments have less control [Genovese, E. 1997: 202]. The interests of shareholders and managers coincided in the field of bulls' market and turned to short-term results [Organisation for Economic Co-operation and Development. 2009: 43]. The need for government intervention in private property was dictated by the interests of society and financial stability. Private ownership is dispersed with a majority shareholder in the face of state.

Given the characteristics of corporate governance will apply theory ,principal-agent“ by the approach SMART (Shareholders, Managers, Auditors, Regulators, Tools) [Nedelchev, M. 2004: 7]. We will attempt to look at the modern corporation and private property at the beginning of the XXI century.

Shareholders participated passively in corporate governance. Protected by international principles and guaranteed by national laws, the shareholders delegated the decision making to the managers and focused on short-term dividends. Limited liability of shareholders for the obligations of the company led to excess risk taking by managers and violation of the public interest.

For protection of financial stability and the interests of society, the state replaced shareholders in corporate governance. To tackle the economic recession companies were stabilized by government lending and government guarantees. Competent national authorities temporarily acquired a majority stake in the ownership of leading companies and started to serve control over managers. Between the state and shareholders arise new agency problem between majority and minority shareholders opposed to the traditional agency problem in A. Berle and G. Means - between shareholders and managers [La Porta, R., F. Lopez-de-Silanes, A. Shleifer. 1999: 471]. The presence of different types of shareholders determines the trend in their actions for change the composition of managers to be reactive rather than proactive [Organisation for Economic Co-operation and Development. 2009: 31].

The shareholders of the modern corporation should take responsibility for private property and incur financial losses. Their participation in corporate governance should be responsible according to the company's goals for creating value in the long term [International Corporate Governance Network. 2009: 19]. New regulatory requirements are forcing shareholders to be active in the management of the company by exercising the voting right. The control of shareholders was restored by regulatory requirements to adopt new policies for managers' remuneration.

Managers were financial encouraged to take excessive risk. The management of delegated property began to be used for purposes which damaged the financial stability and public interests.

To deal with the effects of the economic recession the participation of managers in corporate governance was put on a qualitatively new level. The state, as a majority 
shareholder after the financial intervention to stabilize the companies, gets the right to make changes in management, including establishment over half the number of managerial staff [European Commission. 2008: 8]. International organizations have set new principles for managers for increased responsibility on disclosure of financial results and the accompanying principles on corporate governance. The new dimensions for the participation of the managers in corporate governance include directors, independent of managers and the presence of significant attempt to control corporate management for the benefit of shareholders. To reduce the „risk appetite“ for managers introduced new international requirements and national policies for remuneration linked to long-term financial results.

Auditors are involved in corporate governance because of the limited liability for shareholders and the need for control over managers [Fohlin, C. 2003: 17]. The main function of auditors is warning: providing of information on the financial results to shareholders and regulators [Organisation for Economic Co-operation and Development. 2005: 22].

The role of auditors in reducing the information asymmetry was reduced because of the conflict of interest in the provision of services in auditing and advising. The interests of the auditors and internal stakeholders in corporate governance, shareholders and managers, coincided with reporting of increased financial results as the risk was outsourced outside the company - to bondholders and models of deposit insurance.

After a series of bankruptcies in 2003 and international initiatives to tackle the economic recession from 2007, to the auditors were introduced requirements for a periodic rotation and mandatory tendering procedure in the selection of a new auditor. Audit companies were prohibited from providing their customers with services other than auditing, such as advising.

The globalization of major audit companies lead to complexity of their structure and management that reduced the transparency of their actions. The concentration and expansion of audit companies imposes the need of regulators to be confident in the quality of audit [Basel Committee on Banking Supervision. 2008: 11]. The control function over audit companies was entrusted to public authorities for transparency of organizational structures and unbundling of the audit and advising.

Regulators involved in corporate governance to avoid the mistakes of the market, thus creating public goods [Pigou, A. 1938: 4]. Expectations for the prudential supervision of the activities of the companies are not justified because the government policy to promote regional competitiveness.

One of the main factors led to the economic recession is insufficient oversight of macroeconomic level [European Central Bank. 2010]. Applied policy „too big to fail“ creates moral hazard, which encouraged shareholders and managers to use riskily the assets of the company at the expense of society and government [Bebchuk, L., H. Spamann. 2009: 14]. Consequences of the economic recession were took mainly from taxpayers and large number of small and medium enterprises [European Parliament. 2010].

For protection interests of society and economic stability, the state financially support leading companies as acquired in them property through buying shares. After acquisition of majoritarian part from ownership the state began to control shareholders, managers and auditors. The main goal, the state to correct the practices of the companies through the acquisition of shares, was not achieved. Financial injections from the state changed the competitiveness of certain companies. After the financial intervention of the state, the concentration of the market is increase as a number of large EU banks with assets larger than the gross domestic product of origin country increased from 10 to 15 .

Since 2007 state intervention in private property terminates model of liberalism [Beffa J. -L., X. Ragot. 2008: 457]. Since 2008, in the EU were introduced new requirements for 
companies receiving assistance that limit shareholders to acquire new assets over the next three years, and managers to pay dividends after a certain period of time. European banking groups, received financial assistance, were restructured by the state through splitting them into small banks. In 2010, US law was passed Dodd-Frank Act which allows regulators to compartmentalize large financial institutions. Purpose of the law is profits and losses to be borne by each bank, and not of her customers. The meaning of the requirement is taxpayers' money that saved banks, to not use for speculation for enrichment of shareholders and managers.

Tools in corporate governance include practices to remove the agent problem and reduce information asymmetry.

In the modern corporation shareholders regained control over managers through policies on remuneration. International organizations have introduced new standards in determining the financial incentives of managers. Aim of the standards is tying of the variable part of the remuneration with term performance of managers. Policies of the companies on remuneration were applied after its approval by general meeting of shareholders. For protection interests of private property from opportunistically behavior of the managers was introduced a remuneration committee, composed of independent directors.

For reduction of information asymmetry towards modern corporations were imposed varicose requirements for disclosure of information including financial and non-financial reports. The managers have an increased liability under disclosure of information about enclosed principles on corporate governance. The purpose of the requirements is to provide accurate and timely information on the results and the company's obligations to society, shareholders and potential investors.

\section{Conclusion}

The events of 2007 posed new challenges to global economy. Were introduced new policies and practices on corporate governance to protect the interests of society and the economic stability.

Economic development at Great Depression of 1930s and eighty years later, at economic recession, have similarities, which are connected with shortcomings in corporate governance. Separation of control from ownership in both historical moments leads to taking of an excessive risk for high profits, which should borne by society and the economy. State intervention in corporate governance by providing funds is not effective because of abuses by managers.

The modern corporation, after the financial intervention, is dependent by the state. Instead to regulate companies, the state they managed as majority shareholder. Globalization of activities of companies add to participation of the state and actions of international organizations when control over managers.

Private property is dispersed with majority shareholder in the face of the state. The state performs dual role on controlling and managing private property. The conflict of interests in state participation additionally increases the agent problem between majority and minority shareholders.

\section{References}

Basel Committee on Banking Supervision. 2008. External audit quality and banking supervision. December. Basel.

Bebchuk, L., H. Spamann. 2009. Regulating Bankers' Pay. Discussion Paper No. 641.

Beffa J. -L., X. Ragot. 2008. La fin du modele liberal-financier. Commentaire, P., 122: 457-460. 
Berle, A., G. Means. 1932. The Modern Corporation and Private Property. Harcourt, Brace and World, New York.

Bratton, W. 2001. Berle and Means Reconsidered at the Century's Turn. The Journal of Corporation Law, Spring: 737-770.

Davis, G. 2011. The Twilight of the Berle and Means Corporation. Seattle University Law Review, 34: 1121-1138.

European Central Bank. 2010. Opinion of the European Central Bank of 26 October 2009 on a proposal for a regulation of the European Parliament and of the Council on Community macro-prudential oversight of the financial system and establishing a European Systemic Risk Board and a proposal for a Council decision entrusting the European Central Bank with specific tasks concerning the functioning of the European Systemic Risk Board.

European Commission. 2008. Communication from the Commission - The application of State aid rules to measures taken in relation to financial institutions in the context of the current global financial crisis. 2008/C 270/02.

European Parliament. 2010. Regulation (EU) No 1092/2010 of the European Parliament and of the Council of 24 November 2010 on European Union macro-prudential oversight of the financial system and establishing a European Systemic Risk Board.

Fohlin, C. 2003. The History of Corporate Ownership and Control in Germany. In: R. Morck (ed.). The History of Corporate Governance: The Rise and Sometimes Fall of the World's Great Mercantile Families. University of Chicago Press.

Genovese, E. 1997. Secularism in the General Crisis of Capitalism. American Journal of Jurisprudence, 42: 195-210.

International Corporate Governance Network. 2009. ICGN Global Corporate Governance Principles: Revised (2009). ICGN, London.

La Porta, R., F. Lopez-de-Silanes, A. Shleifer. 1999. Corporate Ownership Around the World. Journal of Finance, 54 (2): 471-517.

Means, G. 2009. Implications of the Corporate Revolution in Economic Theory. In A. Berle, G. Means. The Modern Corporation \& Private property. Tenth printing. Transaction Publishers, New Brunswick.

Mizruchi, M. 2004. Berle and Means revisited: the governance and power of large U.S. corporations. Theory and Society, 5: 579-617.

Nedelchev, M. 2004. Corporate governance in banking system. Ciela, Sofia.

Organisation for Economic Co-operation and Development. 2005. OECD guidelines for insurers' governance. OECD.

Organisation for Economic Co-operation and Development. 2009. Corporate Governance and the Financial Crisis: Key Findings and Main Messages. OECD.

Pigou, A. 1938. The Economics of Welfare. MacMillan \& Co., London.

Weidenbaum, M., M. Jensen. 2009. Introduction to the Transaction Edition. In A. Berle, G. Means. The Modern Corporation \& Private property. Tenth printing. Transaction Publishers, New Brunswick. 